\title{
Long-term grazing effects on genetic variation in Idaho fescue
}

\author{
DAVID MATLAGA AND KEITH KAROLY
}

Authors are Graduate Student, Department of Biology, University of Miami, Coral Gables, Fla, 33124; and Associate Professor, Biology Department, Reed College, Portland, Ore., 97202. At the time of the research, the senior author was an undergraduate student, Biology Department, Reed College, Portland, Ore. 97202.

\section{Abstract}

The effect of cattle grazing on the genetic structure of native grass populations has received little attention. We investigated the effect of cattle grazing on genetic variation in Idaho fescue (Festuca idahoensis Elmer) using ISSR (inter-simple sequence repeat) DNA markers. The ISSR markers are hypervariable and are generally interpreted as being selectively neutral. Idaho fescue tillers were sampled from inside $(\mathbf{N}=31)$ and outside $(\mathrm{N}=$ 34) a 64-year-old cattle exclosure in southeastern Oregon. We extracted DNA and used 2 ISSR primers to determine the genotypes for grazed and ungrazed plants at 60 variable loci. No statistically significant differences were observed between grazed and ungrazed samples for percent polymorphic loci $($ grazed $=$ $85 \%$; ungrazed $=80 \%$ ), mean expected heterozygosity (grazed $=$ 0.1393 ; ungrazed $=0.1365$ ), or for a measure of loci dissimilarity (grazed $=0.506$; ungrazed $=0.536$ ). We also found that the ungrazed individuals sampled inside the exclosure were not significantly genetically differentiated from the grazed individuals sampled outside the exclosure $\left(G_{s t}=\mathbf{0 . 0 0 0 8}\right.$ averaged across all loci). Our results differ from past studies that found demographic and physiological differences between Idaho fescue inside and outside of grazing exclosures at the same site. Our results mirror those of other researchers who have also failed to detect genetic differences at marker loci in response to grazing. We propose that either the mechanisms that must be present to cause changes in neutral genetic variation are not affected by cattle grazing for Idaho fescue at this site, or that any effects of grazing on neutral genetic variation were overwhelmed by gene flow between the grazed and ungrazed samples.

Key Words: cattle grazing, Inter-Simple Sequence Repeat markers, Festuca idahoensis, Monte Carlo procedure

There has been a general decline in the abundance and distribution of caespitose grasses of the shrub steppe region of western North America over the last 100 years (Mack and Thompson 1982). Grazing by livestock has often been cited as a possible cause of this decline because grasses native to this region did not

The authors would like to thank Tony Svejcar and Sara Runkel for assistance with field collection and Pedro Quintana-Ascencio for assistance with statistical analyses. Aaron Liston and two anonymous reviewers provided valuable comments on the manuscript. This research was supported by a grant to David Matlaga from the Howard Hughes Medical Institute made to Reed College under the 1996 Undergraduate Biological Sciences Initiative

Manuscript accepted 15 Aug. 03

\section{Resumen}

El efecto del apacentamiento del ganado en la estructura genética de poblaciones de zacates nativos ha recibido poca atención. Usando marcadores ISSR (secuencia repetida inter-simple ) de DNA investigamos el efecto del apacentamiento del ganado en la variación genética del "Idaho fescue" (Festuca idahoensis Elmer). Los marcadores ISSR son hipervariables y generalmente son interpretados que son selectivamente neutrales. Se muestrearon hijuelos de "Idaho fescue" dentro $(\mathrm{N}=31)$ y fuera ( $N=34)$ de una área excluida del ganado de 64 años de antiguiedad situada en el sudeste de Oregon. Extrajimos el DNA y usamos 2 bibliotecas de ISSR para determinar los genotipos de las plantas apacentadas y no apacentadas en 60 loci viables. No se observaron diferencias estadísticamente significativas entre las muestras apacentadas y no apacentadas para el porcentaje de loci polimórficos $($ apacentado $=85 \% ;$ no apacentado $=80 \%$ ), la media esperada de heteocigocidad (apacentada $=0.1393$; no apacentada $=\mathbf{0 . 1 3 6 5}$ ) o para una medida de disimilaridad de loci $($ apacentada $=0.506 ;$ no apacentada $=0.536)$. También encontramos que los individuos no apacentados muestreados dentro de la exclusión no fueron significativamente diferenciados genéticamente de los individuos apacentados muestreados fuera de la exclusión $\left(\mathrm{G}_{\mathrm{st}}=\mathbf{0 . 0 0 0 8}\right.$ promediado a través de todos los loci). Nuestros resultados difieren de estudios pasados que encontraron diferencias demográficas y fisiológicas entre el "Idaho fescue" de dentro y fuera de exclusiones al apacentamiento ubicadas en el mismo sitio. Nuestros resultados reflejan aquellos de otros investigadores quienes también han fallado en detectar diferencias genéticas en loci marcados en respuesta al apacentamiento. Proponemos que, en este sitio, tanto los mecanismos que deben estar presentes para causar cambios en la variación genética neutral del "Idaho fescue" no son afectados por el apacentamiento del ganado o que cualquiera de los efectos del apacentamiento en la variación genética neutral son superados por el flujo genético entre las muestras apacentadas y no apacentadas.

co-evolve with large ungulates making them less grazing tolerant (Mack and Thompson 1982). Researchers have investigated a diversity of ecological mechanisms by which grazing may have impacted native grass populations in western North America, including the selectivity of cattle based on plant morphology, the seasonal and yearly diet breadth of cattle, and the effect of grazing on mycorrhiza colonization and plant density (Holecheck et al. 1982, Bethlenfalvay et al. 1984, Sheehy and Vavra 1996). Only rarely have researchers included measures of neutral genetic 
variation while investigating the impact of grazing on native grass populations (Carman and Briske 1985, Tómas et al. 2000, Liston et al. 2003). When grazing affects ecological features of plants such as population size and gene flow, this should in turn influence genetic variation measured at selectively neutral markers. Changes in genetic variation can therefore be expected to provide important insights into the mechanisms by which native grass populations are affected by grazing.

We investigated the effect of long-term cattle grazing on neutral genetic variation in samples of Idaho fescue (Festuca idahoensis Elmer). Neutral genetic markers allowed us to study the indirect effects (i.e. changes in population size or gene flow) of cattle grazing rather than the direct effects (i.e. selection for grazing tolerence). Reductions in population size or restrictions of gene flow that could result from grazing would be expected to reduce genetic variation at neutral loci. Alternately, grazing could increase genetic variation, either by a direct mechanism where the substitution rate of mutations increases due to herbivore damage (Marcotrigiano 2000), or indirectly from genome-wide selection for increased genetic variation due to environmental stress (Keane et al. 1999). We used DNAbased, inter-simple sequence repeat (ISSR) markers to quantify genetic variation in adjacent grazed and ungrazed samples that have been part of a long-term ( 64 year) cattle grazing exclosure study. The ISSR method uses primers based on microsatellite (simple sequence repeat or SSR) di- or tri-nucleotide motifs to amplify DNA fragments corresponding to regions between matching microsatellite loci. Because the ISSR method uses SSR (microsatellite) loci as priming sites, it is expected that these markers will be distributed throughout the nuclear genome (Wolfe and Liston 1998). The ISSR markers can detect high levels of genetic polymorphism, even in plant populations where allozyme diversity is often minimal or entirely absent (Esselman et al. 1999).

\section{Material and Methods}

Idaho fescue is a long-lived tetraploid $(2 n=4 x=28)$ grass native to the shrub steppe of western North America (Darlington and Wylie 1955). Within the intermountain west, and specifically in the shrub steppe plant community of southern Oregon, Idaho fescue is a dominant species (Lentz and Simonson 1986). Idaho fescues' range extends north into southern Canada, south to Arizona, and east to eastern Colorado. Idaho fescue has been deemed "vigorous" in relation to cattle grazing (Pond 1960) and is a predominant component of the diets of cattle in the western United States (Jaindl et al. 1994). The study site is a juniper (Juniperus occidentallis Hook), low sagebrush (Artemesia arbuscula Nutt.), high desert ecosystem, where Idaho fescue is abundant. We sampled Idaho fescue from inside and near 1 of the 13 cattle grazing exclosures established in 1936 at the Northern Great Basin Experimental Range (NGBER; $43.483^{\circ} \mathrm{N}$, $\left.119.717^{\circ} \mathrm{W}\right)$ in southeastern Oregon. Previous researchers observed differences in physiological and demographic traits between grazed and ungrazed Idaho fescue at NGBER (Doescher et al. 1997, Liston et al. 2003).

Idaho fescue individuals were collected from pasture 13 at NGBER in January 2000. Prior to establishment of the grazing exclosure in 1936, range conditions were poor due to continuous grazing of cattle and sheep since the late 1800s (Rose et al. 1994). The criteria used when selecting the exclosure locations at NGBER were not recorded (Sneva et al. 1984) but it is thought that the exclosures were simply erected in the center of each experimental pasture (personal communication Tony Svejcar). The exclosure is $250 \times 63 \mathrm{~m}$, with the long dimension oriented in an eastwest direction. We chose to exclude from our sampling an area inside the exclosure that was part of a burn treatment because it was not replicated outside. This reduced the sampling area inside the exclosure to $200 \times 63 \mathrm{~m}$. Sampling of grazed individuals was conducted on an area of the same size immediately south of the exclosure. One hundred plants were sampled in total, 50 from inside the exclosure and 50 from outside. Sampling of both $200 \times 63 \mathrm{~m}$ areas (grazed and ungrazed) was carried out in a stratified random fashion by breaking the $63 \mathrm{~m}$ width of each area into three, $21 \mathrm{~m}$ sections. Fence posts placed every $3 \mathrm{~m}$ along the long dimension of the exclosure were used as a sampling guide. Of the 67 fence posts along the $200 \mathrm{~m}$ length, 17 posts were randomly excluded to make a sample of 50 for both grazed and ungrazed areas. At each of these 50 posts, one of the $21 \mathrm{~m}$ sections was chosen at random and walked in a north to south direction until the first Idaho fescue plant was found. Groups of tillers were removed using a hammer and chisel due to the frozen ground. Approximately 5 tillers from each individual were potted and grown in the
Reed College greenhouse for 3 weeks until green material was present. Green tissue was only produced on 31 individuals from inside the exclosure and 36 from outside the exclosure.

Genomic DNA was extracted from each individual using QIAGEN DNeasy plant extraction kits. Approximately $50 \mathrm{mg}$ of fresh tissue was first frozen in liquid nitrogen and then ground and extracted according to the manufacturer's protocol. All DNA samples were randomly numbered to obscure their site of origin to avoid bias. Samples were amplified and run on gels in this randomized order. The ISSR primers 842 (GAGAGAGAGAGAGAGAYA) and 835 (AGAGAGAGAGAGAGAGYC) from the University of British Columbia's ISSR primer set were used in PCR reactions to amplify DNA fragments. Amplification began after the template DNA was added to reaction tubes while being held at $70^{\circ} \mathrm{C}$ and proceeded as follows: 1 minute $94^{\circ} \mathrm{C}$ denaturation, followed by 34 cycles of 25 seconds at $94^{\circ}$ C, 30 seconds at $50^{\circ} \mathrm{C}, 2$ minutes and 5 seconds at $72^{\circ} \mathrm{C}$, a final 5 minutes at $72^{\circ}$ $\mathrm{C}$, and then held at $4^{\circ} \mathrm{C}$. All PCR reactions were carried out a second time for each plant sample and the 2 replicates were run side by side on a $2 \%$ agrose gel (Sigma), with a 100 bp ladder (New England Biolabs) used as a size standard. Gels were scanned on a Flour-S gel scanner (BioRad) to produce digital images, which were analyzed using the Quantity One software package. Bands (loci) were scored based on their presence or absence, which was resolved using the magnification tool in the Quantity One software. Two of the samples from outside the exclosure yielded no bands in any of the amplifications. Because of the low probability of observing a multilocus genotype with null alleles at each of the loci we scored, we interpreted this result as failed amplification and excluded these samples from all analyses. This left a final sample size of 31 individuals from inside and 34 from outside the exclosure.

Genetic variation for plants inside and outside the exclosure was quantified as the number of unique multilocus genotypes in each sample, percent polymorphic loci (P), mean expected heterozygosity $\left(\mathrm{H}_{\mathrm{e}}\right.$, averaged across loci), and using a dissimilarity index based on band sharing $\left(\mathrm{D}_{\mathrm{xy}}\right.$; Lynch 1990). Inter-simple sequence repeat markers are dominant, with band absence reflecting homozygosity of the recessive null allele (Wolfe and Liston 1998). For expected heterozygosity, we used the unbiased estimator described by Lynch 
and Milligan (1994) for dominant markers, including adherence to their recommendation of excluding all loci for which the null allele frequency was less than $3 / \mathrm{N}$. Although Idaho fescue is a tetraploid, Liston et al. (2003) observed disomic inheritance for allozyme loci in their study of Idaho fescue at NGBER. To calculate the allele frequencies necessary for estimating $\mathrm{H}_{\mathrm{e}}$, we assumed both disomic inheritance and that our samples were in Hardy-Weinberg equilibrium. The second assumption was justified based on Liston et al.'s (2003) observation of HardyWeinberg equilibrium for allozyme loci in their study of Idaho fescue and NGBER. We also determined the magnitude of genetic differentiation $\left(\mathrm{G}_{\mathrm{st}}\right)$ between the 2 samples, calculated as both 1) the mean $\mathrm{G}_{\mathrm{st}}$ across all loci, and 2) using the mean estimates of $\mathrm{H}_{\mathrm{e}}$ for the total sample and the subsamples from inside and outside the exclosure (Culley et al. 2002).

The association between grazing status and number of polymorphic loci was examined using a contingency test. To further examine the difference between grazed and ungrazed samples, we used a Monte Carlo randomization procedure that was carried out for 1,000 iterations using Resampling Stats for Excel (Blank 2001). In this procedure we randomly assigned (without replacement) the 65 observed ISSR multilocus genotypes to 1 of 2 groups (with $N=31$ and $N=34$ ). Our measures of genetic diversity $\left(\mathrm{P}, \mathrm{H}_{\mathrm{e}}\right.$, and $\mathrm{D}_{\mathrm{xy}}$ ) were then calculated for each group, and the difference between the 2 groups was recorded for each measure. The observed difference between the samples inside and outside the exclosure for each measure of genetic diversity was then compared with the distribution of 1,000 values from the Monte Carlo data to test the null hypothesis that the observed difference was due to chance. The null hypothesis was rejected and the observed difference was judged to be significant at the $5 \%$ alpha-level if the observed value was more extreme than the empirically observed $95 \%$ confidence interval found for the Monte Carlo data for each diversity statistic (e.g. more extreme than the $25^{\text {th }}$ or $976^{\text {th }}$ among the ranked Monte Carlo values).

\section{Results}

Primer 835 amplified a total of 34 bands, ranging in size from 190 to 1500 bp. Primer 842 amplified a total of 26 bands, ranging in size from 300 to 1050 bp. Overall we observed 63 multilocus genotypes in our sample of 64 plants. All plants within the grazed and the ungrazed samples possessed unique, multilocus ISSR genotypes, while a single, multilocus genotype was shared between 2 plants from the 2 samples.

Overall, we found no evidence in any of our genetic measures that genetic variation differed between the 2 samples. The grazed sample displayed 3 more polymorphic loci than were observed in the ungrazed sample, but this difference was not significant based on either a contingency test $\left(X^{2}=0.52, p=0.47\right)$ or the Monte Carlo procedure (Table 1). Expected heterozygosity $\left(\mathrm{H}_{\mathrm{e}}\right)$ was greater in the grazed sample, but the difference was slight and not statistically significant. The measure of band dissimilarity $\left(D_{x y}\right)$ showed an opposite pattern, with greater dissimilarity inside the exclosure, but this difference was not statistically significant. The differentiation between samples was minimal and not statistically significant (mean $\mathrm{G}_{\mathrm{st}}$ across loci was 0.0008 , the $\mathrm{G}_{\mathrm{st}}$ based on mean heterozygosities was 0.0397). For both calculations of $\mathrm{G}_{\mathrm{st}}$, the observed value was well inside the empirical $95 \%$ confidence intervals based on the 1,000 Monte Carlo iterations (a rank of 624 for the mean $G_{s t}$, and a rank of 748 for the $G_{s t}$ based on the mean $H_{e}$ ).

\section{Discussion}

We observed high levels of genetic variation based on percent polymorphic loci and number of unique genotypes in Idaho fescue using inter-simple sequence repeat (ISSR) markers. While we know of no specific tests of neutrality for ISSR variation, the general interpretation is that they represent non-coding sequence (Wolfe and Liston 1998) and they have therefore been interpreted as selectively neutral (Wolfe et

Table 1. Measures of genetic diversity for Idaho fescue sampled from inside (ungrazed) and adjacent to (grazed) a cattle exclosure at the Northern Great Basin Experimental Range.

\begin{tabular}{|c|c|c|c|c|c|}
\hline Measure & Grazed & Ungrazed & $\begin{array}{c}\text { Difference } \\
\text { (grazed-ungrazed) }\end{array}$ & $\begin{array}{l}\text { Monte Carlo } \\
95 \% \text { C.I. }\end{array}$ & $\begin{array}{l}\text { Monte } \\
\text { Carlo } \\
\text { Rank }\end{array}$ \\
\hline $\begin{array}{l}\text { Polymorphic } \\
\text { loci }(\%)\end{array}$ & 85 & 80 & 5 & -10 to 15 & 714 \\
\hline
\end{tabular}

Mean

\begin{tabular}{llllll}
$\begin{array}{c}\text { Heterozygosity } \\
\left(\mathrm{H}_{\mathrm{e}}\right)\end{array}$ & 0.1393 & 0.1365 & 0.0028 & -0.0187 to 0.0200 & 573 \\
$\begin{array}{c}\text { Dissimilarity } \\
\text { index }\left(\mathrm{D}_{\mathrm{xy}}\right)\end{array}$ & 0.506 & 0.536 & -0.030 & -0.055 to 0.055 & 829 \\
\hline
\end{tabular}

${ }^{1}$ Monte Carlo estimates at this rank and below were equal to or less extreme than the observed difference (based on 1,000 Monte Carlo iterations). al. 1998a, 1998b). Simple sequence repeat (SSR or microsatellite) loci are scattered throughout the genome (Hancock 1999) and are commonly interpreted as representing non-coding regions that are not influenced by natural selection (Wolfe and Liston 1998, Schlötterer and Wiehe 1999; but see Kashi and Soller 1999 for a contrasting view). Because ISSR loci represent short sequences between SSR loci, ISSRs are also expected to be neutral and scattered throughout the genome. Their positions throughout the genome should minimize any influence on their variability that could result from linkage to non-neutral loci (Wolfe et al. 1998a, 1998b). Our results are consistent with the findings of other researchers, who also observed high variation (overall $85 \%$ polymorphic loci) in Idaho fescue at the Northern Great Basin Experimental Range (Liston et al. 2003). Our results differ from the level of genetic diversity reported by Esselman et (1999) in their ISSR survey of their much lower measure of percent polymorphic loci $(\mathrm{P}=24 \%)$ likely reflects the rarity and high clonality of that native grass. The ISSR method has been found to detect more variation then either allozymes or randomly amplified polymorphic DNAs (RAPDs; Esselman et al. 1999). Like RAPDs, no prior knowledge of the Idaho fescue genome was needed for us to use this method, but unlike RAPDs, the ISSR method is more repeatable (Wolfe and Liston 1998) and less expensive (Yang et al. 1996).

Contrary to our expectations, the percent polymorphic loci $(\mathrm{P})$, mean expected heterozygosity $\left(\mathrm{H}_{\mathrm{e}}\right)$, number of unique genotypes, and genetic dissimilarity $\left(\mathrm{D}_{\mathrm{xy}}\right)$ were not significantly different between our grazed and ungrazed samples. Similar results were observed in 2 studies that 
investigated genetic effects of grazing using allelic diversity at isozyme markers. Carman and Briske (1985) failed to observe a difference in genetic variability (measured at 3 allozyme loci) in grazed and ungrazed samples of little bluestem (Schizachyrium scoparium (Michx.) Nash. var. frequens (FT.Hubb.) Gould) in Kansas. Tómas et al. (2000) did not observe differences in allozyme genetic variability at 3 loci when comparing samples of a native forage grass (Piptochaetium napostaense (Speg.) Hack) either exposed to grazing by cattle, grazing by a native rodent, or protected from grazers by an exclosure for 20 years. In their study of sexual and clonal recruitment in Idaho fescue from a different Northern Great Basin Experimental Range pasture than ours, Liston et al. (2003) also failed to detect any difference in genetic diversity at ISSR loci between plants sampled from inside and outside a grazing exclosure.

Our negative result does not guarantee that grazing has had no affect on Idaho fescue during the 64 years the cattle exclosure has been in place at the Northern Great Basin Experimental Range. Other researchers have noted differences for Idaho fescue at NGBER between grazed and ungrazed sites. Doesher et al. (1997) found physiological differences between Idaho fescue individuals taken from inside and outside one of the grazing exclosures at this site. Those differences persisted when plants were grown in a common garden, suggesting a genetic basis for the difference between grazed and ungrazed individuals. Liston et al. (2003) sampled Idaho fescue from a $9 \mathrm{~m}^{2}$ permanent plot in an ungrazed exclosure at NGBER and observed a greater number of small plants when compared to individuals sampled from an equivalent sized permanent plot in the adjacent, grazed portion of the pasture. They also noted greater clone fragmentation in the ungrazed plot, which they hypothesized to be the result of litter accumulation. At other sites, long-term cattle grazing of Idaho fescue has been found to reduce overall plant height, leaf length, and reproductive shoot height (Fahnestock and Detling 2000). Changes in morphology in response to grazing have been reported in a diversity of plant species for traits such as leaf blade width (Gray and Scott 1980, Carman and Briske 1985), leaf angle (Smith 1998), and silica content (McNaughton et al. 1985, Cid et al. 1989). However, to the extent the traits are genetically determined, these changes in physiology and morphology are most likely adaptive responses to selection that would only be reflected by allele frequency changes in the coding regions of the genome. In the absence of linkage between trait and marker loci, such direct genetic changes would not be observed in a survey that sampled only neutral genetic variation.

In a comparison of current plant distributions with fine-scale maps made in 1937 , Idaho fescue individuals at the Northern Great Basin Experimental Range were found to be long-lived (as long as 60 years; Liston et al. 2003). Their analysis also showed that sexual recruitment of Idaho fescue has occurred during the time since the grazing exclosures were first established at NGBER, with a 10-fold increase in the number of individuals in their permanent plots over the past 60 years. Given sufficient time and the clear evidence of other impacts from grazing, why has neutral genetic variation not been affected? We believe there are 2 biological reasons why we did not observe a genetic effect of grazing for plants in our study. First, our results may show that the ecological mechanisms we expected to produce a difference in neutral genetic variation (changes in population size, gene flow and mutation) are not impacted by grazing at this site. However, results from other studies have generally found that these ecological features of plant populations are directly affected by herbivory. Grazing has been shown to reduce the fecundity of an invasive annual (Grigulis et al. 2001), decrease seedling size and increase seedling density in several species (Milton 1995), increase seedling emergence in both grass and composite species (Oesterheld and Osvaldo 1990, Bullock et. al 1994), and extend the season of recruitment in a grass (Butler and Briske 1988). Grazing or herbivory have also been found to influence characters related to fecundity and gene flow (Rausher and Feeney 1980, Doak 1992, Molinillo and Farjibrener 1993, Bullock et. al 1994, Quesada et. al 1995, Lehtila and Strauss 1997, Herrera 2000, Juenger and Bergelson 2000, Mothershead and Marquis 2000, Smith et al. 2000, Van Der Wal et al. 2000). This wealth of evidence that herbivory does affect ecological traits that are expected to impact the distribution of neutral genetic variation leads us to favor a second explanation for our observation that grazing has not affected genetic variation in Idaho fescue at NGBER.

Although grazing may have impacted traits expected to affect neutral genetic variation in Idaho fescue at the Northern Great Basin Experimental Range, this effect may have been overwhelmed at the scale of our sampling by gene flow between plants inside and outside the grazing exclosure. The plants in our study showed minimal and non-significant genetic differentiation between the grazed and ungrazed samples. Liston et al.'s (2003) estimate of genetic differentiation $\left(\mathrm{G}_{\mathrm{ST}}\right)$ between their grazed and ungrazed samples in their pasture was the same magnitude as our estimate. Within each of their permanent plots where they sampled all individuals, they also failed to detect a significant relationship between physical distance and genetic dissimilarity. Tómas et al. (2000) also invoked gene flow to help explain their failure to observe genetic differences between grazed and ungrazed plants in their study. Grasses rely on wind to disperse pollen (and sometimes seeds), and thus gene flow can occur over a large distance (pollen in grasses can be moved as far as $800 \mathrm{~m}$; Richards 1986). The scale of dispersal of wind-pollinated species could make it necessary for grazing exclosures to be very large to detect a genetic change in response to grazing. However, researchers must be wary of the trade-off that exists between increases in exclosure size and the introduction of between-site differences. Large exclosures will limit the opportunity for gene flow between grazed and ungrazed plants, but will necessarily increase the distance between the samples of grazed and ungrazed individuals. While limiting the homogenizing effects of gene flow, an increased distance between grazed and ungrazed plants will increase the likelihood that between-site differences other than grazing, such as microhabitat, may contribute to differences in genetic structure, with the consequence that any observed genetic difference may be incorrectly attributed to the impacts of grazing.

\section{Literature Cited}

Bethlenfalvay, G. J., J. Gabor, and D. Suren. 1984. Grazing effects on mycorrhizal colonization and floristic composition of the vegetation on a semiarid range in northern Nevada. J. Range Manage. 37:312-316.

Blank, S. 2001. Resampling Stats for Excel, version 2.0. Resampling Stats Inc., Arlington, Virg.

Bullock, J.M., B.C. Hill, and J. Silvertown. 1994. Demography of Cirsium vulgare in a grazing experiment. J. Ecol. 82:101-111.

Butler, J.L. and D.D. Briske. 1988. Population structure and tiller demography of the bunchgrass Schizachyrium scoparium in response to herbivory. Oikos 51:306-312. 
Carman, J.G. and D.D. Briske. 1985. Morphological and allozymic variation between long-term grazed and non-grazed populations of the bunchgrass Schizachyrium scoparium var. frequens. Oecologia 66:332-337.

Cid, M.S., J.K. Detling, M.A. Brizuela, and A.D. Whicker. 1989. Patterns in grass silicification: response to grazing history and defoliation. Oecologia 80:268-271.

Culley, T.M., Wallace, L.E., Gengler-Nowak, K.M., and D.J. Crawford. 2002. A comparison of two methods of calculating $G_{\mathrm{ST}}$, a genetic measure of population differentiation. Amer. J. Bot. 89:460-465.

Darlington, C.D. and A.P. Wylie. 1955. Chromosome Atlas of Flowering Plants. Second edition. George Allen and Unwin Ltd., London.

Doak, D.F. 1992. Lifetime impacts of herbivory for a perennial plant. Ecol. 73:20862099.

Doescher, P.S., T.J. Svejcar, and R.G. Jaindl. 1997. Gas exchange of Idaho fescue in response to defoliation and grazing history. J. Range Manage. 50:285-289.

Esselman, E. J., L. Jianqiang, D. J. Crawford, J. L. Winduss, and A. D. Wolfe. 1999. Clonal diversity in the rare Calamagrostis porteri ssp. insperata (Poaceae): comparative results for allozymes and random amplified polymorphic DNA (RAPD) and inter simple sequence repeat (ISSR) markers. Mol. Ecol. 8:443-451.

Fahnestock, J.T. and J.K. Detling. 2000. Morphological and physiological responses of perennial grasses to long-term grazing in the Pryor Mountains, Montana. Amer. Midl. Nat. 143:312-320.

Gray, A.J. and R. Scott. 1980. A genecological study of Puccinellia maritima Huds. (Parl.). New Phytol 85:89-107.

Grigulis, K., A.W. Sheppard, J.E. Ash, and R.H. Groves. 2001. The comparative demography of the pasture weed Echium plantagineum between its native and invaded ranges. J. Appl. Ecol. 38:281-290.

Hancock, J. M. 1999. Microsatellites and other simple sequences: genomic context and mutational mechanism, p. 1-9. In: Goldstein, D. B., and C. Schlötterer (eds.) Micro-satellites: evolution and applications. Oxford Univ. Press, N.Y.

Herrera, C.M. 2000. Measuring the effects of pollinators and herbivores: evidence for nonadditivity in a perennial herb. Ecol. 81:2170-2176.

Holecheck, J.L., M. Vavra, J. Skovlin, and W.C. Krueger. 1982. Cattle diets in the Blue Mountains of Oregon. I. Grasslands. J. Range Manage. 35:109-1 12.

Jaindl, R.G., P. Doescher, R.F. Miller, and L.E. Eddleman. 1994. Persistance of Idaho fescue on degraded rangelands: Adaptation to defoliation or tolerance? J. Range Mange. 47:54-59.

Juenger, T. and J. Bergelson. 2000. Does early season browsing influence the effect of self-pollination in scarlet gillia? Ecol. 81:41-48.
Kashi, Y. and M. Soller. 1999. Functional role of microsatellites and minisatellites, $\mathrm{p}$. 10-23. In: Goldstein, D. B., and C. Schlötterer (eds.) Microsatellites: evolution and applications. Oxford Univ. Press, N.Y.

Keane, B., S. Pelikan, G.P. Toth, M.K. Smith, and S.H. Rogstad. 1999. Genetic diversity of Typha latifolia (Typhaceae) and the impact of pollutants examined with tandem-repetitive DNA probes. Amer. J. Bot. 86:1226-1238.

Lehtila, K. and S.Y. Strauss. 1997. Leaf damage by herbivores affects attractiveness to pollinators in wild radish, Raphanus raphanistrum. Oecologia 111:396-403.

Lentz, R.D. and G.H. Simonson. 1986. A detailed soils inventory and associated vegetation of Squaw Butte Range Experimental Station. Ore. State Univ. Agr. Exp. Sta. Spec. Rep. 760, Corvallis, Ore.

Liston, A., B.L. Wilson, W.A. Robinson, P.S. Doescher, N.R. Harris, and T. Svejcar. 2003. The relative importance of sexual reproduction verus clonal spread in an aridland bunchgrass. Oecologia 137:216-225.

Lynch, M. 1990. The similarity index and DNA fingerprinting. Mol. Biol. Evol. 7:478-484.

Lynch, M. and B. G. Milligan. 1994. Analysis of population genetic structure with RAPD markers. Mol. Ecol. 3:91-99.

Mack, R.N. and J.N. Thompson. 1982. Evolution in steppe with few large, hooved mammals. Amer. Nat. 119:757-773.

Marcotrigiano, M. 2000. Herbivory could unlock mutations sequestered in stratified shoot apicies of genetic mosaics. Amer. J. Bot. 87:355-361.

McNaughton, S.J., J.L. Tarrants, M.M. McNaughton, and R.H. Davis. 1985. Silica as a defense against herbivory and a growth promotor in African grasses. Ecol. 66:528-535.

Milton, S.J. 1995. Spatial and temporal patterns in the emergence and survival of seedlings in arid Karoo shrubland. J. Appl. Ecol. 32:145-156.

Molinillo, M.F. and A.G. Farjibrener. 1993. Technical Note: Cattle as a dispersal agent of Acaena elongata (Rosacea) in the cordillera of Merida, Venezuela. J. Range Manage. 46:557-561

Mothershead, K. and R.J. Marquis. 2000. Fitness impacts of herbivory through indirect effects on plant-pollinator interactions in Oenothera macrocarpa. Ecol. 81:30-40.

Oesterheld, M. and S.E. Osvaldo. 1990. Effects of grazing establishment: the role of seed and safe-site availability. J. Veg. Sci. 1:353-358.

Pond, P.W. 1960. Vigor of Idaho fescue in relation to different grazing intensities. J. Range Manage. 13:23-27.

Quesada, M., K. Bollman, and A.G. Stephenson. 1995. Leaf damage decreases pollen production and hinders pollen performance in Cucurbita texana. Ecol. 76:437-443.

Rausher, D. and P. Feeny. 1980. Herbivory, plant density, and plant reproductive success: the effect of Battus philenor on Aristolochia reticulata. Ecol. 61:905-917.
Richards, A.J. 1986. Plant breeding systems. George Allen and Unwin, Boston, Mass.

Rose, J.A., R.F. Miller, and T. Svejcar. 1994. Vegetation and livestock exclusion in the sagebrush steppe. Manage. of Great Basin rangelands Ann. Rep. 1994. Agr. Exp. Sta., Ore. State Univ. in cooperation with the U.S.D.A., Agr. Res. Service. Corvallis, Ore.

Schlötterer, C. and T. Wiehe. 1999. Microsatellites, a neutral marker to infer selective sweeps, p. 238-248. In: Goldstein, D. B., and C. Schlötterer (eds.) Microsatellites: evolution and applications. Oxford Univ. Press, NY.

Sheehy, D.P. and M. Vavra. 1996. Ungulate foraging areas on seasonal rangeland in Northestern Oregon. J. Range Manage. 49:16-23.

Smith, S.E. 1998. Variation in response to defoliation between populations of Bouteloua curtipendula var. caespitosa (Poaceae) with different livestock grazing histories. Amer. J. Bot. 85:1266-1272.

Smith, S.E., R. Mosher, and D. Fendenheim. 2000. Seed production in sideoats grama populations with different grazing histories. J. Range Manage. 53:550-555.

Sneva, F.A., L.R. Rittenhouse, P.T. Tueller, and $P$. Reece. 1984. Changes in protected and grazed sagebrush-grass in Eastern Oregon, 1937 to 1974. Sta. Bull. 663. Agr. Exp. Sta., Ore. State Univ., Corvallis, Ore.

Tómas, M.A., A.D. Carrera, and M. Poverene. 2000. Is there any genetic differentiation among populations of Piptochaetium napostaense (Speg.) Hack (Poaceae) with different grazing histories? Plant Ecol. 147:227-235.

Van Der Wal, R., M. Egas, A. VanDer Veen, and J. Bakker. 2000. Effects of resource competition and herbivory on plant performance along a natural productivity gradient. J. Ecol. 88:317-330.

Wolfe, A. D. and A. Liston. 1998. Contributions of PCR-based methods to plant systematics and evolutionary biology, $p$. 43-86. In: Soltis D. E., P. S. Soltis, and J. J. Doyle (eds.) Molecular systematics of plants. II. DNA sequencing. Kluwer Acad. Pub., Boston, Mass.

Wolfe A. D., Q. Xiang, and S.R. Kephart. 1998a. Diploid hybrid speciation in Penstemon (Scrophulariaceae). Proc. Nat. Acad. Sci., USA 95: 5112-5115.

Wolfe A. D., Q. Xiang, and S.R. Kephart. 1998b. Assessing hybridization in natural populations of Penstemon (Scrophulariaceae) using hypervariable inter-simple sequence repeat (ISSR) bands. Mol. Ecol. 7:1107-1125.

Yang, W., A.C. de Oliveira, I. Godwin, K. Shertz, and J.L. Bennetzen. 1996. Comparison of DNA marker technologies in characterizing plant genome diversity: variability in Chinese sorghums. Crop Sci. 36:1669-1676. 